\title{
ASH FUSIBILITY CHARACTERISTICS OF SOME BIOMASS FEEDSTOCKS AND EXAMINATION OF THE EFFECTS OF INORGANIC ADDITIVES
}

\author{
Giuseppe Toscano, Fabrizio Corinaldesi
}

\section{Introduction}

The interest in using agricultural waste, refuse and other biomass feedstocks as fuels for steam and power generation is growing steadily throughout the world, due to the high cost of fossil fuels in terms of purchase as well as of disposal in line with environmental regulations [Vamvuka 2003]. However, burning biomass for energy production induces varying degrees of ash agglomeration on the heat transfer surface of boilers, resulting in reduced energy efficiency, difficult cleaning of apparatuses from the ash deposits, and even mechanical failure of heat exchangers [Llorente Fernandez 2006]. The main cause of these problems is the high alkaline content, and consequently the low melting temperature, of the ash of some biomass feedstocks, particularly herbaceous materials, which also contain more ash than woody biomass [Llorente Fernandez 2005]. Biomass fuels contain several substances, including $\mathrm{K}, \mathrm{Na}, \mathrm{S}$ and $\mathrm{Cl}$. During combustion these elements may give rise to molten phases which produce sticky ash particles that adhere to heat transfer surfaces [Werklin 2005]. This can lower the ash melting temperature, enhancing the adhesion efficiency of fly ash particles [Theis 2006]. It has been demonstrated that the addition of oxides and inorganic salts to the initial biomass can change its thermal behaviour and raise its melting temperature [Werther 2000; Zintl 1998; Van Ommen 2001; Vuthaluru 2001; Llorente Fernandez 2006]. Several works have explored the effect of feedstock supplementation with calcium and magnesium oxide, silica and limestone [Malte 2008; Fan 1984; Bhattacharya 2003]. After providing an overview of the characteristics of the inorganic fraction of some biomass types, we describe the effect on ash thermal behaviour with

Paper received 17.07.2008; accepted 19.08.2010

Dr. GIUSEPPE TOSCANO, researcher, Dept. SAIFET, Polytechnic University of Marche, via Brecce Bianche, Monte Dago, 60131, Ancona, g.toscano@univpm.it

Dr. FABRizio CoRINALdESI, PhD student, Dept. SAIFET. Polytechnic University of Marche, f.corinaldesi@univpm.it the addition of calcium oxide $(\mathrm{CaO})$, silicon oxide $\left(\mathrm{SiO}_{2}\right)$, magnesium oxide $(\mathrm{MgO})$, and calcium carbonate $\left(\mathrm{CaCO}_{3}\right)$ to corn grain $(\mathrm{CG})$, sunflower cake (SC), and wheat straw (WS).

\section{Materials and methods}

The experimental activity involved in this work was articulated in three phases.

\subsection{Determination of biomass ash characteristics}

In the first phase we determined the quantitative and qualitative characterisation of the inorganic fraction of 20 biomass materials (tab. 1), including agri-

\begin{tabular}{|c|c|c|}
\hline No. & Biomass feedstock & Type \\
\hline 1 & Wheat & \\
\hline 2 & Durum wheat (grains) & Amylaceous biomass \\
\hline 3 & Dent corn (grains) & \\
\hline 4 & Flint corn (grains) & \\
\hline 5 & Spruce & \\
\hline 6 & Beech & \\
\hline 7 & Wood (chips) & Woody biomass \\
\hline 8 & Olive tree prunings & $(\mathrm{WB})$ \\
\hline 9 & Vine prunings & \\
\hline 10 & Sawdust & \\
\hline 11 & Corn (whole plant) & \\
\hline 12 & Sorghum (chips) & Herbaceous biomass \\
\hline 13 & Wheat (straw) & $(\mathrm{HB})$ \\
\hline 14 & Rice (straw) & \\
\hline 15 & Olive residues & \\
\hline 16 & Grape residues & \\
\hline 17 & Sunflower cake & Agro-industrial \\
\hline 18 & Rape cake & (AR) \\
\hline 19 & Citrus residues & \\
\hline 20 & Wheat bran & \\
\hline
\end{tabular}

TABLE 1 - Biomass feedstocks analysed. 
cultural by-products and residues, forestry residue and crop discards, chosen as representative of the widely heterogeneous agro-industrial and forestry feedstocks, to provide a reference framework for the thermal behaviour of biomass ash.

The ash content $\left(A_{c}\right)$ of the 20 biomass feedstocks was determined according to the CEN/TS 14775 standard; the materials were assigned to the CEN/TS 14961 classes on the basis of their $A_{c}$, expressed as a proportion of dry matter The $A_{c}$ range of each class, defined using the general master table for the specification of the properties of other solid biofuels (CEN/TS 14961), is reported in table 2.

\begin{tabular}{|c|c|}
\hline \multirow{2}{*}{$\begin{array}{c}\text { CEN/TS 14961 } \\
\text { classes }\end{array}$} & Ash content $\left(\boldsymbol{A}_{\boldsymbol{c}}\right)$ range \\
\cline { 2 - 2 } & $(\%$ d.m. $)$ \\
\hline A3 & $0-3$ \\
\hline A6 & $3-6$ \\
\hline A10 & $6-10$ \\
\hline A $>10$ & $>10$ \\
\hline
\end{tabular}

TABLE 2 - Feedstock classification based on ash content.

The second phase involved determination of the fusibility temperature of the ash of the 20 feedstocks. To do this ash was obtained by burning each biomass feedstock in a muffle incinerator at $550{ }^{\circ} \mathrm{C}$ and then subjected to granulometry reduction, to obtain a more homogeneous fine powder. Its fusibility temperature was determined in an oxidising atmosphere according to CEN/TS 15370, using an ash fusion analyser (IF 2000F, Sylab company) whose upper limit of detection was $1550{ }^{\circ} \mathrm{C}$. The procedure involved preparation in a metal mould of a regular, cylindrical, solid test piece to be introduced into the ash fusion analyser. Fusibility analysis is based on detecting changes in the physical state (i.e. shape) of the test piece subjected to a rising temperature gradient, using an image recognition system made up of a video camera connected to a computer; an ad hoc software identifies sample geometry, where four main melting phases can be distinguished in relation to four characteristic temperatures, i.e. shrinkage, deformation $\left(D_{T}\right)$, hemisphere and flow temperature $\left(F_{T}\right)$ (CEN/TS 15370). $D_{T}$ is the most informative parameter to understand the behaviour of ash in the boiler and the temperature at which agglomeration may arise. The fusibility test data allow a subdivision of the materials into quality categories in relation to the typical operating temperatures of biomass combustion plants.

The $D_{T}$ range of each proposed category is listed in table 3. The operating temperature of large plants, where some of the biomass feedstocks considered are burned, generally ranges between $850^{\circ} \mathrm{C}$ and $1000^{\circ} \mathrm{C}$ [Sjaak 2008]. Ash deposits form on the surface of heat exchange banks at flue gas temperatures less than

\begin{tabular}{|c|c|}
\hline \multirow{2}{*}{ Ash quality categories } & $\begin{array}{c}\text { Range of deformation } \\
\text { temperature }\left(\boldsymbol{D}_{T}\right)\end{array}$ \\
\cline { 2 - 2 } & $\left({ }^{\circ} \boldsymbol{C}\right)$ \\
\hline Low melting & $<1000$ \\
\hline Medium melting & $1000-1300$ \\
\hline High melting & $>1300$ \\
\hline
\end{tabular}

TABLE 3 - Classification of biomass in relation to ash melting temperatures.

$1000^{\circ} \mathrm{C}$ [Van Loo 2008]. The maximum fuel bed temperatures that apply in grate combustion of biomass materials are generally of the order of $1000-1200^{\circ} \mathrm{C}$, and the overall residence time on the grate is relatively long, usually several minutes [Van Loo 2008]. Fusion temperatures in excess of $1300^{\circ} \mathrm{C}$ are therefore believed not to cause problems.

\subsection{Measurement of data repeatability}

The method used to determine the ash melting temperature also envisages the possibility of determining measurement error. Preparation of the cylindrical test pieces is particularly critical, since the system's sensitivity in recognising their shape changes along the temperature gradient depends on their regular shape. Since current standards provide no indications on how to assess method accuracy or data repeatability, the tests of some ash samples, CG, WS and SC (selected for their low melting temperature), were run 6 times. Simple, descriptive statistics were applied to the results.

\subsection{Biomass material supplementation with mineral additives}

In the third phase of the work, known quantities of $\mathrm{CaO}, \mathrm{SiO}_{2}, \mathrm{MgO}$ and $\mathrm{CaCO}_{3}$ mineral additives $(>90$ $\%$ purity) were added to $\mathrm{CG}$ ash to examine to what extent it affected its melting temperature [Werther 2000; Zintl 1998; Van Ommen 2001; Llorente Fernandez 2006, Malte 2008, Fan 1984]. These minerals are already found in variable amounts in biomass ash and have a very high melting temperature. CG ash, ground in a hammer mill fitted with a $1 \mathrm{~mm}$ grid and dried on a stove at $105^{\circ} \mathrm{C}$, was supplemented with 4 different additive concentrations $\left(A_{d}\right): 0.25 \% ; 0.5 \% ; 0.75 \% ; 1$ $\%$. The 16 mixtures thus obtained were processed in the same way as the ash material (granulometry reduction and muffle incineration) and then subjected to fusibility analysis (CEN/TS 15370). Their fusibility temperatures were correlated with additive type and dose. The two additives inducing the strongest effects on $D_{T}$, with $A_{d}$ equal to or less than $0.5 \%$, were added to WS and SC for a fusibility analysis by the same procedure. 


\section{Results}

The findings of the first two phases, i.e. the $A_{c}$ and $D_{T}$ of each sample, are reported in table 4 . The $A_{c}$ of the 20 biomass feedstocks ranged widely, from $0.5 \%$ to ca. $15 \% . D_{T}$, the most informative parameter to understand the behaviour of ash in the boiler and the temperature at which agglomeration may arise, also showed widely different values that ranged from 800 ${ }^{\circ} \mathrm{C}$ up to more than $1500^{\circ} \mathrm{C}$.

The quality and quantity findings are illustrated in diagram form in figure 1 . The data are reported on a grid as the $D_{T}$ to $A_{c}$ ratio, which defines the quality category of each material. Their distribution shows that the different feedstocks tend to form separate groups: $\mathrm{WB}$, which have low $A_{c}$ and high $D_{T}$, cluster on the upper left side; $\mathrm{HB}$ are arranged in the middle; $\mathrm{AB}$, which have low $A_{c}$ but low melting temperature, cluster on the lower left side, whereas AR, which include materials of different origins and types, are scattered.

\subsection{Assessment of data repeatability}

Tables 5, 6 and 7 report the results of the fusibility analysis of CG, WS and SC, respectively, including the melting temperature of each of the 6 test pieces and their mean, standard deviation (SD), and coefficient of variability $(C V)$. The variability of $D_{T}$ was quite narrow $(C V<1 \%)$.

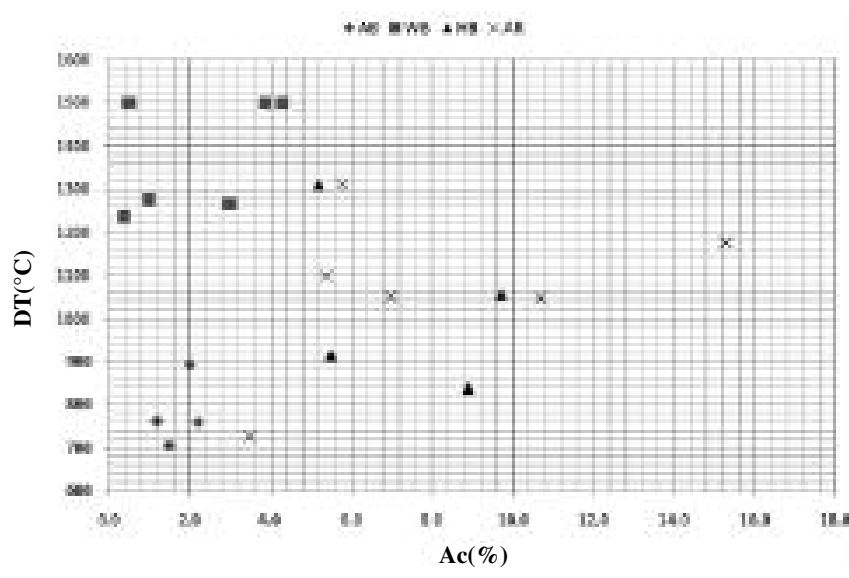

WB: Woody biomass; HB: herbaceous biomass; AB: amylaceous biomass; AR: agro-industrial residues.

Fig. 1 - Qualitative and quantitative characterisation of the ash of the 20 biomass materials examined.

\subsection{Change in ash fusibility temperature after feedstock supplementation with the mineral additives}

The results of the fusibility tests of additive-supplemented ash are reported in table 8, where the mean ash fusibility temperatures of the six CG tests runs without additives (tab. 5) are used as the baseline.

The same data are reported in figure 2, where the increased deformation temperature is correlated with additive concentrations. $\mathrm{MgO}$ was the most effective

\begin{tabular}{|c|c|c|c|c|c|}
\hline \multirow{2}{*}{ No. } & \multirow{2}{*}{ Biomass feedstock } & \multirow{2}{*}{ Type } & $A_{c}$ & $D_{T}$ & $F_{T}$ \\
\hline & & & $(\%)$ & $\left({ }^{\circ} \mathrm{C}\right)$ & $\left({ }^{\circ} \mathbf{C}\right)$ \\
\hline 1 & Wheat & \multirow{4}{*}{$\begin{array}{l}\text { Amylaceous biomass } \\
\text { (AB) }\end{array}$} & 2.2 & 760 & 819 \\
\hline 2 & Durum wheat (grains) & & 2.0 & 891 & 965 \\
\hline 3 & Dent corn (grains) & & 1.2 & 761 & 814 \\
\hline 4 & Flint corn (grains) & & 1.5 & 706 & 791 \\
\hline 5 & Spruce & \multirow{6}{*}{$\begin{array}{l}\text { Woody biomass } \\
\text { (WB) }\end{array}$} & 0.4 & 1236 & 1280 \\
\hline 6 & Beech & & 0.5 & 1500 & $>1500$ \\
\hline 7 & Wood chips & & 3.0 & 1266 & 1350 \\
\hline 8 & Olive tree prunings & & 4.3 & 1500 & $>1500$ \\
\hline 9 & Vine prunings & & 3.9 & 1500 & $>1500$ \\
\hline 10 & Sawdust & & 1.0 & 1277 & 1356 \\
\hline 11 & Corn (whole plant) & \multirow{4}{*}{$\begin{array}{l}\text { Herbaceous biomass } \\
\text { (HB) }\end{array}$} & 5.2 & 1311 & 1373 \\
\hline 12 & Sorghum chips & & 5.5 & 914 & 1208 \\
\hline 13 & Wheat (straw) & & 8.9 & 839 & 1244 \\
\hline 14 & Rice (straw) & & 9.7 & 1057 & 1371 \\
\hline 15 & Olive residues & \multirow{6}{*}{$\begin{array}{l}\text { Agro-industrial } \\
\text { residues } \\
\text { (AR) }\end{array}$} & 10.7 & 1046 & 1177 \\
\hline 16 & Grape residues & & 5.8 & 1310 & 1380 \\
\hline 17 & Sunflower cake & & 5.4 & 1098 & 1224 \\
\hline 18 & Rape cake & & 7.0 & 1051 & 1119 \\
\hline 19 & Citrus residues & & 15.3 & 1175 & 1196 \\
\hline 20 & Wheat bran & & 3.5 & 726 & 875 \\
\hline
\end{tabular}

TABLE 4 - Combined biomass ash classification. 


\begin{tabular}{|c|c|c|c|c|}
\hline $\begin{array}{c}\text { Test piece } \\
\text { No. }\end{array}$ & $\begin{array}{c}\text { Shrinkage } \\
\text { temperature } \\
\left({ }^{\circ} \mathbf{C}\right)\end{array}$ & $\begin{array}{c}\text { Deformation } \\
\text { temperature } \\
\left({ }^{\circ} \mathbf{C}\right)\end{array}$ & $\begin{array}{c}\text { Hemisphere } \\
\text { temperature } \\
\left({ }^{\circ} \mathbf{C}\right)\end{array}$ & $\begin{array}{c}\text { Flow } \\
\text { temperature } \\
\left({ }^{\circ} \mathbf{C}\right)\end{array}$ \\
\hline 1 & 742 & 756 & 805 & 811 \\
2 & 772 & 763 & 800 & 809 \\
3 & 609 & 752 & 803 & 808 \\
4 & 710 & 761 & 805 & 813 \\
5 & 671 & 772 & 809 & 821 \\
6 & 663 & 759 & 810 & 822 \\
\hline Mean & $\mathbf{6 9 5}$ & $\mathbf{7 6 1}$ & $\mathbf{8 0 5}$ & $\mathbf{8 1 4}$ \\
\hline SD & 58.9 & 6.8 & 3.7 & 6.1 \\
CV (\%) & 8.5 & 0.9 & 0.5 & 0.8 \\
\hline
\end{tabular}

TABLE $\quad 5-$ Results of six test runs (corn grain).

\begin{tabular}{|c|c|c|c|c|}
\hline $\begin{array}{c}\text { Test piece } \\
\text { No. }\end{array}$ & $\begin{array}{c}\text { Shrinkage } \\
\text { temperature } \\
\left({ }^{\circ} \mathbf{C}\right)\end{array}$ & $\begin{array}{c}\text { Deformation } \\
\text { temperature } \\
\left({ }^{\circ} \mathbf{C}\right)\end{array}$ & $\begin{array}{c}\text { Hemisphere } \\
\text { temperature } \\
\left({ }^{\circ} \mathbf{C}\right)\end{array}$ & $\begin{array}{c}\text { Flow } \\
\text { temperature } \\
\left({ }^{\circ} \mathbf{C}\right)\end{array}$ \\
\hline 1 & 745 & 844 & 1131 & 1215 \\
2 & 743 & 830 & 1105 & 1258 \\
3 & 748 & 845 & 1130 & 1251 \\
4 & 752 & 828 & 1080 & 1250 \\
5 & 753 & 848 & 1085 & 1258 \\
6 & 749 & 841 & 1101 & 1233 \\
\hline Mean & $\mathbf{7 4 8}$ & $\mathbf{8 3 9}$ & $\mathbf{1 1 0 5}$ & $\mathbf{1 2 4 4}$ \\
\hline SD & 3.9 & 8.3 & 21.6 & 17.0 \\
CV $(\boldsymbol{\%})$ & 0.5 & 1.0 & 2.0 & 1.4 \\
\hline
\end{tabular}

TABLE 6 - Results of six test runs (wheat straw).

\begin{tabular}{|c|c|c|c|c|}
\hline $\begin{array}{c}\text { Test piece } \\
\text { No. }\end{array}$ & $\begin{array}{c}\text { Shrinkage } \\
\text { temperature } \\
\left({ }^{\circ} \mathbf{C}\right)\end{array}$ & $\begin{array}{c}\text { Deformation } \\
\text { temperature } \\
\left({ }^{\circ} \mathbf{C}\right)\end{array}$ & $\begin{array}{c}\text { Hemisphere } \\
\text { temperature } \\
\left({ }^{\circ} \mathbf{C}\right)\end{array}$ & $\begin{array}{c}\text { Flow } \\
\text { temperature } \\
\left({ }^{\circ} \mathbf{C}\right)\end{array}$ \\
\hline 1 & 927 & 1099 & 1131 & 1228 \\
2 & 925 & 1094 & 1127 & 1222 \\
3 & 932 & 1092 & 1152 & 1212 \\
4 & 925 & 1098 & 1145 & 1264 \\
5 & 912 & 1100 & 1142 & 1204 \\
6 & 919 & 1103 & 1155 & 1213 \\
\hline Mean & $\mathbf{9 2 3}$ & $\mathbf{1 0 9 8}$ & $\mathbf{1 1 4 2}$ & $\mathbf{1 2 2 4}$ \\
\hline SD & 6.9 & 4.0 & 11.2 & 21.4 \\
CV $(\boldsymbol{\%})$ & 0.8 & 0.4 & 1.0 & 1.7 \\
\hline
\end{tabular}

TABLE 7 - Results of six test runs (sunflower cake). 


\begin{tabular}{|c|c|c|c|c|}
\hline $\begin{array}{c}\text { Additive } \\
\text { concentration } \\
(\%) \\
\end{array}$ & $\begin{array}{c}\text { Shrinkage } \\
\text { temperature } \\
\left({ }^{\circ} \mathbf{C}\right) \\
\end{array}$ & $\begin{array}{c}\text { Deformation } \\
\text { temperature } \\
\left({ }^{\circ} \mathbf{C}\right) \\
\end{array}$ & $\begin{array}{c}\text { Hemisphere } \\
\text { temperature } \\
\left({ }^{\circ} \mathbf{C}\right) \\
\end{array}$ & $\begin{array}{c}\text { Flow } \\
\text { temperature } \\
\left({ }^{\circ} \mathbf{C}\right) \\
\end{array}$ \\
\hline 0 & 695 & 761 & 805 & 814 \\
\hline \multicolumn{5}{|c|}{$\mathrm{SiO}_{2}$} \\
\hline 0.25 & 764 & 986 & 1236 & 1315 \\
\hline 0.5 & 800 & 1260 & 1382 & 1425 \\
\hline 0.75 & 874 & 1419 & $>1500$ & $>1500$ \\
\hline 1 & 858 & 1457 & $>1500$ & $>1500$ \\
\hline \multicolumn{5}{|c|}{ MgO } \\
\hline 0.25 & 1163 & 1329 & 1458 & 1464 \\
\hline 0.5 & 1347 & 1406 & 1477 & $>1500$ \\
\hline 0.75 & 1329 & 1456 & $>1500$ & $>1500$ \\
\hline 1 & 1406 & 1463 & $>1500$ & $>1500$ \\
\hline \multicolumn{5}{|c|}{$\mathrm{CaO}$} \\
\hline 0.25 & 978 & 1072 & 1140 & 1170 \\
\hline 0.5 & 1209 & 1441 & 1459 & $>1500$ \\
\hline 0.75 & 1308 & $>1500$ & $>1500$ & $>1500$ \\
\hline 1 & $>1500$ & $>1500$ & $>1500$ & $>1500$ \\
\hline \multicolumn{5}{|c|}{$\mathrm{CaCO}_{3}$} \\
\hline 0.25 & 743 & 1020 & 1032 & 1040 \\
\hline 0.5 & 1007 & 1134 & 1186 & 1199 \\
\hline 0.75 & 1155 & 1225 & 1301 & 1358 \\
\hline 1 & 1230 & 1447 & 1466 & $>1500$ \\
\hline
\end{tabular}

TABLE 8 - Ash melting temperatures of corn grain supplemented with mineral additives.

additive in raising the $D_{T}$ of $C G$ ash. In particular, the addition of $0.25 \% \mathrm{MgO}$ raised it from $756^{\circ} \mathrm{C}(\mathrm{CG}$ without additives) to $>1400^{\circ} \mathrm{C}$. $\mathrm{CaO}$ was slightly less effective. Finally, $0.8 \% \mathrm{SiO}_{2}$ and $1 \% \mathrm{CaCO}_{3}$ were required to achieve a $D_{T}>1400^{\circ} \mathrm{C}$.

Figures 3 and 4 describe the effect on ash thermal behaviour of WS and SC supplementation with $\mathrm{MgO}$

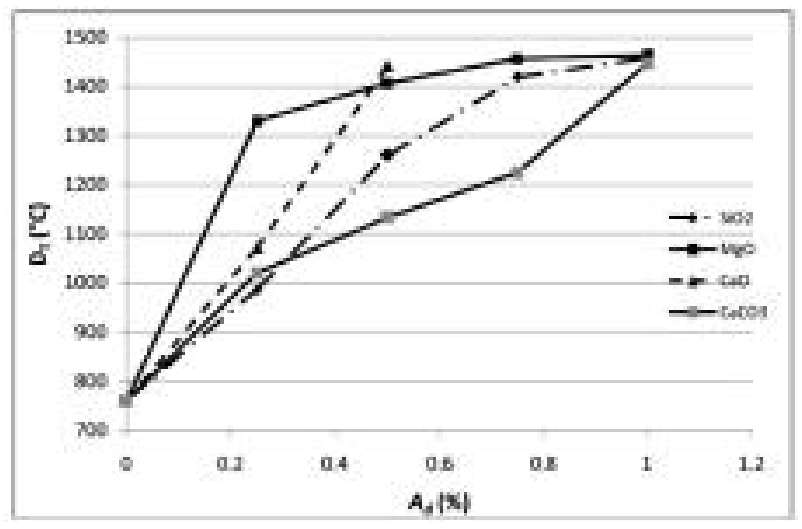

Fig. 2 - Deformation temperature $\left(\mathrm{D}_{\mathrm{T}}\right)$ of corn grain ash as a function of additive concentration $\left(\mathrm{A}_{\mathrm{d}}\right)$. and $\mathrm{CaO}$, the two additives that proved to be the most effective in the tests with CG. $D_{T}$ increased in both feedstocks, but not as much as it did with CG. The increase was between $250^{\circ} \mathrm{C}$ and $350^{\circ} \mathrm{C}$ in the case of WS, and was greater using $\mathrm{MgO}$, especially at $A_{d}$ less than $0.5 \%$, whereas when $1 \%$ of $\mathrm{MgO}$ was added to SC the gain was barely $200^{\circ} \mathrm{C}$.

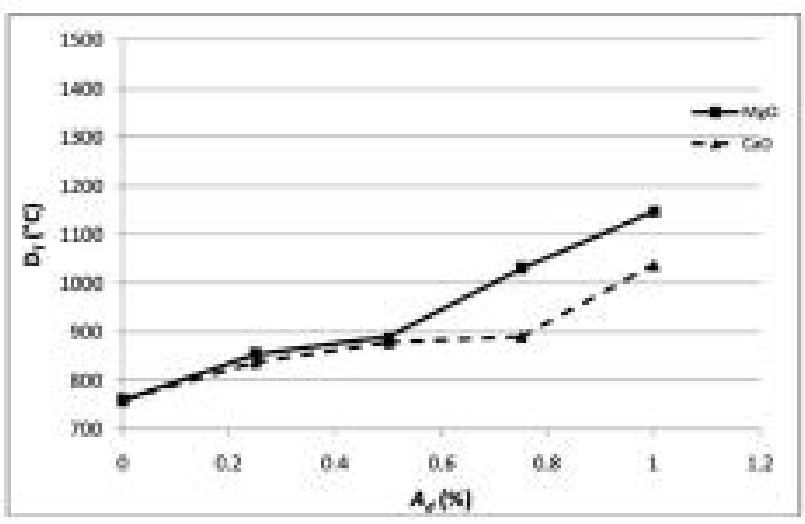

Fig. 3 - Deformation temperature $\left(\mathrm{D}_{\mathrm{T}}\right)$ of wheat straw ash as a function of additive concentration $\left(\mathrm{A}_{\mathrm{d}}\right)$. 


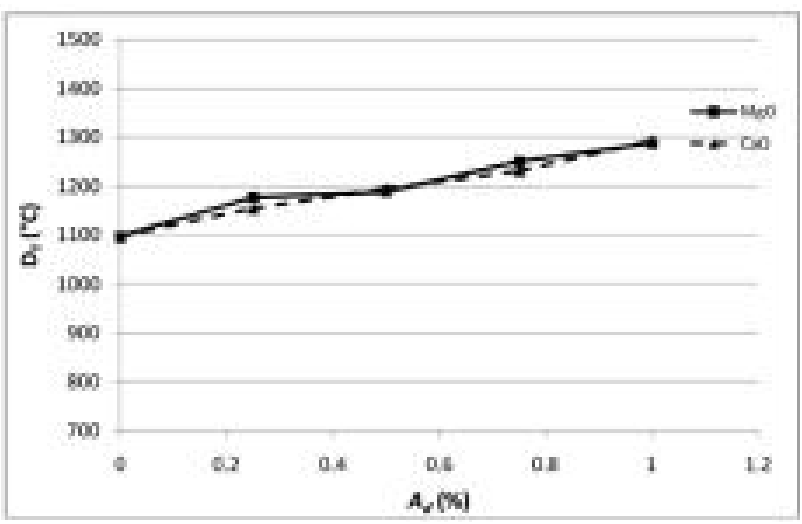

Fig. 4 - Deformation temperature $\left(\mathrm{D}_{\mathrm{T}}\right)$ of sunflower cake ash as a function of additive concentration $\left(\mathrm{A}_{\mathrm{d}}\right)$.

\section{Conclusions}

Analysis of biomass feedstocks based on their inorganic fraction demonstrated a very broad range of values of ash content and deformation temperature. Since materials with similar origin were seen to have comparable quality, it is conceivable that feedstocks that were not analysed here will be found to contain similar inorganic fractions as tested feedstocks having similar quality. Nevertheless, supplementation with inorganic additives was able to change the thermal behaviour of some feedstock and to improve their ash melting temperature, though negatively affecting their $A_{C}$. In the materials exhibiting a linear $D_{T}$ response to the additive, it seems possible to calculate the amount of additive, to be added to the initial biomass, that will achieve a stable temperature range. $\mathrm{MgO}$ and $\mathrm{CaO}$ were the most effective of the additives tested, since small amounts exerted a strong effect on $D_{T}$. In particular, ca. $0.2 \%$ of $\mathrm{MgO}$ or $\mathrm{CaO}$ were seen to be required to raise the $D_{T}$ of $\mathrm{CG}$ to a temperature greater than $1300{ }^{\circ} \mathrm{C}$, to achieve a relative $A_{c}$ increase of $12-15 \%$ compared with pure $\mathrm{CG}$, since its value would increase from $1.5 \%$ to approximately $1.7 \%$.

Whereas supplementation with additives was very effective in the case of $\mathrm{CG}$, it did not raise the ash melting temperature of SC and WS to a sufficient extent, possibly due to their different ash content. In other words, the lower the $A_{c}$ content of the additivesupplemented feedstock, the greater the additive's effect in raising $D_{T}$. Achieving the same effect $\left(D_{T}=\right.$ $1300{ }^{\circ} \mathrm{C}$ ) with WS using $\mathrm{MgO}$ would require an $A_{d}$ of about $1.6 \%$. In such case the additive mixture would raise the $A_{c}$ of the biomass feedstock from ca. $8.9 \%$ to ca. $10.5 \%$, whereas achieving the same result with SC would require an $A_{d}$ of $1 \%$, resulting in an increase in the $A_{c}$ of the mixture from $5.4 \%$ to $6.4 \%$.

If these processes can be extended to other biomass types (on which work is now in progress in our laboratory) and, especially, if the effects obtained with the analyser can be reproduced in the actual combustion plant, the decision to use additives and their amount would be dictated by economic factors (cost of purchase and disposal).

\section{References}

Vamvuka D., Zografos D., Predicting the behaviour of ash resulting from burning mixture of biofuels. Part 1: Deposit rates, Fuel, (2003), 83, 2051-2057.

Llorente Fernandez M.J., Laplaza Murillo J.M., Cuadrado Escalda R., Garcia Garrasco J.E., Ash behaviour of lignocellulosic biomass in bubbling fluidised bed combustion, Fuel, (2006) 85, 1157-1165.

Llorente Fernandez M.J., Garcia Garrasco J.E., Comparing methods for predicting the sintering of biomass ash in combustion, Fuel, (2005), 84, 1893-1900.

Werklin J., Skrifvars B.J., Hupa M., Ash-forming elements in four Scandinavian wood species. Part 1: Summer harvest”, Biomass and Bioenergy, (2005), 29, 451-456.

Theis M., Skrifvars B.J., Hupa M., Tran H., Fouling tendency of ash resulting from burning mixtures of biofuels, Part 2: Deposit chemistry, Fuel, (2006), 85, 1125-1130.

Werther J., Saenger M., Hartge E.-U., Ogada T., Siagi Z., Combustion of agricultural residues", Prog Energy Combust Sci, (2000), 26(1), 1-27.

Zintl F., Ohman T., Alkali-induced particle agglomeration and bed-defluidization on CFB-combustion of biomasstest of common and alternative bed materials, Biomass for energy and industry. In: Kopetz W, Palz C, Ferrero, editors. Proceedings of the international conference, Wurzburg, Germany, 8-11 June 1998. Rimpar Germany: C.A.R.M.E.N.; 1998. p. 1581-4.

Van Ommen J.R., Schouten J.C., Coppens M.O., Lin W., Dam-Johansen K., van den Bleek C.M., Timely detection of agglomeration in biomass fired fluidized beds. In: Proceedings of the 16th international conference on fluidized bed combustion, 2001, p. 1146-59.

Vuthaluru H.B., Zhang D.K., Effect of Ca and Mg-bearing minerals on particle agglomeration defluidisation during fluidised-bed combustion of a South Australian lignite. Fuel Process Technol, (2001), 69(1), 13-27.

Vuthaluru H.B., Zhang D.K., Remediation of ash problems in fluidised-bed combustors. Fuel, (2001), 80(4), 583598.

Llorente Fernandez M.J., Cuadrado R.E., Murillo Laplaza J.M., Carrasco Garcia J.E., Combustion in bubbling fluidised bed with bed material of limestone to reduce the biomass ash agglomeration and sintering. Fuel, (2006); 85(14-15): 2081-92.

Malte B., Weigang L., Nijenhuis J., Kapteijn F., Van Ommena J.R., Agglomeration in fluidized beds at high temperatures: Mechanisms, detection and prevention , Progress in Energy and Combustion Science 34 (2008) 633-666.

Fan L., Walawender W.P., Pyrolysis of carbonaceous solids in fluidised bed of quartz sand-using e.g. ground limestone as anti-agglomerant. Patent US4448589-A, (University of Kansas (UNIV)), 1984.

Bhattacharya S.P., Harttig M., Control of agglomeration and defluidization burning high-alkali, high-sulfur lignites in a small fluidized bed combustor- effect of additive size and type, and the role of calcium. Energy Fuels, 2003;17(4): 1014-21.

Van Loo S., Koppejan J., The handbook of biomass cofiring. Earthscan. London (2008) pagg. 442.

CEN/TS 14775:2004, Solid biofuels - Method for the determination of ash content. 
CEN/TS 14961:2005, Solid biofuels - Fuel specification and classes.

CEN/TS 15370-1:2006, Solid biofuels - Method for the determination of ash melting behaviour - Part 1: Characteristic temperatures method.

\section{SUMMARY}

The increased consumption of solid biomass for energy production has raised a number of technical problems that are mainly related to the variability of the chemical-physical characteristics of feedstocks. The low melting temperature of their inorganic fraction is the main cause of these problems. In this work analysis and comparison of the thermal behaviour of ash from 20 different feedstocks highlighted that biomass materials with the same origin share similar qualitative and quantitative characteristics. A feedstock from a starch group, corn grain, was tested for the effects of four mineral additives $(\mathrm{MgO}, \mathrm{CaO}, \mathrm{Ca}-$ $\mathrm{CO}_{3}$, and $\mathrm{SiO}_{2}$ ) on ash deformation temperature. $\mathrm{MgO}$ and $\mathrm{CaO}$ seemed to be the most effective, raising ash melting temperature and enhancing the thermal behaviour of the feedstock. The results of supple- mentation of the initial corn grain, wheat straw and sunflower cake biomass demonstrated that the amount of additive to be used is a function of biomass type and can depend on its ash content.

Keywords: biomass, ash behaviour, melting temperature, inorganic additive.

\section{List of symbols}

$A_{c} \quad$ ash content with reference to dry weight (\%)

$A_{d} \quad$ additive content with reference to dry weight $(\%)$

$C G \quad$ corn grain

WS wheat straw

$S C \quad$ sunflower cake

CV coefficient of variability (\%)

$D_{T} \quad$ deformation temperature $\left({ }^{\circ} \mathrm{C}\right)$

$F_{T} \quad$ flow temperature $\left({ }^{\circ} \mathrm{C}\right)$

$\mathrm{AB}$ amylaceous biomass

WB woody biomass

HB herbaceous biomass

AR agro-industrial residues 
002_Toscano(542)_13 30-11-2010 18:06 Pagina 20 